\title{
SWI/SNF-Related Matrix-Associated Actin- Dependent Regulator of Chromatin Subfamily D Member 1
}

National Cancer Institute

\section{Source}

National Cancer Institute. SWI/SNF-Related Matrix-Associated Actin-Dependent

Regulator of Chromatin Subfamily D Member 1. NCI Thesaurus. Code C19842.

SWI/SNF-related matrix-associated actin-dependent regulator of chromatin subfamily $D$ member 1 (515 aa, $\sim 58 \mathrm{kDa}$ ) is encoded by the human SMARCD1 gene. This protein plays a role in chromatin remodeling, transcriptional regulation and neuronal development. 